\title{
W stronę hermeneutyki gier komputerowych
}

Michał Kłosiński 


\section{W stronę hermeneutyki gier komputerowych ${ }^{1}$}

Michał Kłosiński

TEKSTY DRUGIE 2017, NR 3, S. 51-68

DOI: $10.18318 /$ td.2017.3.4

$\mathbf{N}$ iniejszy tekst stanowi próbę zarysowania szerszego problemu badawczego, który można określić jako hermeneutykę gier wideo. Na polskim gruncie najważniejszy i zarazem najkrótszy artykuł poświęcony temu zagadnieniu, napisany przez Rafała Kochanowicza, dotyczy gier fabularyzowanych ${ }^{2}$. Odwołując się do Nietzscheańskiego nominalizmu, badacz zakłada, że gry komputerowe można traktować na równi z innymi formami

1 W moim tekście wymienne stosuję termin "gra komputerowa" $i$ "gra wideo" ze względu na niepełny charakter obu tych określeń: "gra wideo" kładzie całkowity nacisk na aspekt audiowizualny rozgrywki (a nie to jest przedmiotem mojej refleksji), natomiast "gra komputerowa" w pewnym sensie wyklucza media inne niż potocznie rozumiany komputer (mimo że konsole różnego typu również można określić mianem komputerów).

R. Kochanowicz "Cybernetyczne doświadczenia" - fabularyzowane gry komputerowe w perspektywie hermeneutyki, "Homo Ludens" $2013 \mathrm{nr} 1$ (5). Szerzej o pojęciu gier fabularyzowanych pisał Kochanowicz w tegoż Fabularyzowane gry komputerowe w przestrzeni humanistycznej. Analizy, interpretacje i wnioski z pogranicza poetyki, aksjologii, dydaktyki literatury, Wydawnictwo Naukowe UAM, Poznań 2014.
Michał Kłosiński - dr, adiunkt W INoLP UŚ. Członek: Association des Amis de Jean Baudrillard, Utopian Studies Society oraz The Society for Utopian Studies. Ostatnio opublikował: Świat pęknięty. O poemach naiwnych Czesława Miłosza (2013) oraz Ratunkiem jest tylko poezja Baudrillard - Teoria - Literatura (2015). Kontakt: michal.klosinski@ us.edu.pl 
dyskursywnymi, a ich tekstowe światy dzięki interpretacji funkcjonują tak samo jak np. ich literackie odpowiedniki ${ }^{3}$. Kochanowicz pisze, że:

Na sposób prowadzenia rozgrywki wpływają bowiem także kompetencje hermeneutyczne odbiorcy (wiedza, doświadczenie, świadomość norm społecznych, moralnych etc.), a fikcyjny w planie fabularnym charakter ujętej w grze opowieści już sam z siebie domaga się interpretacji. I to nierzadko wnioski bądź wrażenia, jakie się z interpretacją wiążą, decydują o kolejnych działaniach gracza / współtwórcy - który równocześnie w ten sposób wnosi do gry normy i światopogląd, wyczucie estetyczne i na ich podstawie stara się dookreślić także „nie-zaprojektowane” fragmenty (ma wizję swojego bohatera, w rolę którego się wciela, tak jak i obraz tego, co chce w ukazanym lub współtworzonym świecie zmienić). ${ }^{4}$

Mimo że Kochanowicz pisze głównie o grach fabularyzowanych, nie będzie nadużyciem rozszerzenie jego tezy o interpretacji na gry wideo w ogóle czy przyjęcie, że granica gatunkowa: fabularyzowane/niefabularyzowane, również zalicza się do kompetencji hermeneutycznych odbiorcy, o czym dobitnie świadczy odczytanie przez Jannet Murray gry Tetris jako wyrazu stanu społeczeństwa amerykańskiego lat 905. Poza argumentami na temat interpretacji Kochanowicz wskazuje na kluczowy moment hermeneutycznego ujęcia gier wideo, wychodzącego od fikcjonalności ich opowieści, a zatem od ich świata przedstawionego. Literaturoznawcy to stwierdzenie wydaje się oczywiste, wszakże w obszarze międzynarodowych game studies kwestia fikcjonalności wirtualnych światów okazuje się wyjątkowo problematyczna. Dla przykładu, dwaj uczniowie klasyka badań nad grami wideo Espena Aarsetha: Olli Tapio Leino i Daniel Vella, w swoich pracach doktorskich twierdzą, że wirtualne światy stanowią rozszerzenie faktyczności światów realnych ${ }^{6}$. Przywołani badacze konstruują swoje tezy, sięgając do fenome-

3 R. Kochanowicz „Cybernetyczne doświadczenia”..., s. 121.

4 Tamże, s. 122.

5 J. Horowitz Murray Hamlet on the Holodeck, The MIT Press, Cambridge 1997, s. 143-144. Stanowczej krytyki interpretacji Murray dokonał Markku Eskelinen w tekście The gaming situation, w którym pokazał, że gra zaprojektowana przez Sovietów niekoniecznie miała służyć jako krytyka amerykańskiego społeczeństwa. M. Eskelinen The Gaming Situation, „Game Studies” 2001 Vol. 1, Is. 1, http://www.gamestudies.org/0101/eskelinen/ (08.11.2016).

6 Por. O. Tapio Leino Emotions In Play: On the constitution of emotion in solitary computer game play, IT University of Kopenhagen, Kopenhagen 2010, s. 221; D. Vella The Ludic Subject and the 
nologii w ujęciu takich filozofów jak: Edmund Husserl, Martin Heidegger, Jean-Paul Sartre, Maurice Merleau-Ponty, Paul Ricœur czy Hans-Georg Gadamer.

Oprócz projektów zorientowanych fenomenologicznie funkcjonują również opracowania, których autorami są współpracujący ze sobą Veli-Matti Karhulahti ${ }^{7}$ J Jonne Arjoranta ${ }^{8}$, odwołujące się głównie do hermeneutyki Gadamerowskiej oraz do wcześniejszych klasyków hermeneutyki, jak Friedrich Schleiermacher czy Wilhelm Dilthey. Do prac Ricœura odnosi się natomiast J. Tuomas Harviainen, który zajmuje się jednak głównie grami typu LARP 9 (Live Action Role Playing), a nie grami wideo. Do koncepcji tożsamości narracyjnej Ricœura odwołuje się bezpośrednio Jos de Mul, który proponuje wprowadzić pojęcie tożsamości ludycznej, twierdząc, że gry komputerowe zasadniczo różnią się od narracji ${ }^{10}$. Na podstawie hermeneutyki Gadamerowskiej powstała natomiast książka Miguela Sicarta poświęcona problemom etyki w grach wideo"1. Warto jedynie wspomnieć, że badacze sięgający do Ricœura powołują się w swoich pracach na krytykę jego teorii tożsamości narracyjnej przeprowadzoną przez Dana Zahaviego ${ }^{12}$. Zahavi wskazuje na ograniczenia wynikające z przyjmowania Ricœurowskiego ujęcia tożsamości, a jego krytyka opiera się na założeniu, że struktury narracyjne nie są w stanie ująć tożsamości w jej najbardziej podstawowym i pierwotnym

Ludic Self: Analyzing the 'I-in-the-Gameworld', IT University of Kopenhagen, Kopenhagen 2015, s. 187-189.

7 Por. V.-M. Karhulahti Hermeneutics and Ludocriticism, "Journal of Games Criticism" 2015 Vol. 2, Is. 1. Oraz: V.-M. Karhulahti Double Fine Adventure and the Double Hermeneutic Videogame, FnG '12 Proceedings of the 4th International Conference on Fun and Games, ACM New York, New York 2012.

8 J. Arjoranta Real-Time Hermeneutics Meaning-Making in Ludonarrative Digital Games, Jyväskylä University Printing House, Jyväskylä 2015.

9 Por. J. Tuomas Harviainen A Hermeneutical Approach to Role-Playing Analysis, "International Journal of Role-Playing" 2008 Is. 1.

Por. J. de Mul The game of life. Narrative and ludic identity formation in computer games, w: Handbook of Computer Games Studies, ed. by J. Goldstein, Joost Raessens, The MIT Press, Cambridge MA, 2005, s. 257-261.

11 Por. M. Sicart The Ethics of Computer Games, The MIT Press, London 2009. A także: M. Sicart Play Matters, The MIT Press, London 2014. 
sensie. Pod tym względem jego stanowisko zbliża się do tezy Ryszarda Nycza przedstawionej w Poetyce doświadczenia ${ }^{13}$.

W swoim projekcie hermeneutyki gier wideo przyjmuję za punkt wyjścia myśl Paula Ricœura, co zbliża mnie bardziej do rozważań Kochanowicza ${ }^{14}$ niż do propozycji zagranicznych badaczy z kręgu game studies. Polski autor porusza w swoim artykule kluczową kwestię dwóch stylów hermeneutycznych: zawierzenia i podejrzliwości ${ }^{15}$, o których pisał Ricœur jako dwóch uzupełniających się drogach interpretacji ${ }^{16}$. Dla Kochanowicza style hermeneutyki stanowią analogię dla poczynań gracza w grze - dlatego traktuje on zawierzenie jako podporządkowanie się zasadom, normom etycznym, kulturowym etc., natomiast podejrzliwość jako sprzeciw wobec strategii mających na celu manipulowanie graczem i podporządkowanie jego działań zamysłowi twórców gry ${ }^{\mathbf{1 7}}$. Przedstawione rozumienie dwóch stylów hermeneutycznych jako elementów rozgrywki i działań gracza jest oczywiście bardzo ciekawe, tymczasem mój projekt hermeneutyki gier wideo będzie zorientowany raczej na te dwa style jako dwie uzupełniające się, a nie wykluczające praktyki badawcze pomocne w analizie i interpretacji gier. Kochanowicz twierdzi również, że specyfika gier wideo wymaga modyfikacji dwóch stylów hermeneutycznych ze względu na to, że gry coraz częściej wprowadzają „wirtualny

13 Por. Podsumowanie analizy wiersza Adama Ważyka: „[...] w tej sprawie poeta zdaje się zgadzać z Sartre'm przeciw Ricœurowi): życie nie jest opowieścią. A czego nie da się opowiedzieć - nie da się też zrozumieć (ani dziejów, ani siebie)". R. Nycz Poetyka doświadczenia. Teoria-nowoczesność - literatura, Wydawnictwo IBL PAN, Warszawa 2012, s. 326.

Wskazuję na Kochanowicza jako badacza, który problematyzuje interpretację gry w myśl hermeneutyki - w swojej książce odnosi się on zarówno do Ricœura, jak i do Umberto Eco czy Gadamera, co sprawia, że ze wszystkich wymienionych w pracy myślicieli, jest on najbardziej zorientowany na wykorzystanie hermeneutyki jako teorii literatury, w przeciwieństwie do obcojęzycznych projektów, które w ogromnej większości powstają w obrębie wydziałów lub uniwersytetów o profilu techniczno-technologicznym, przez co ich autorzy nie są tak wyczuleni na problemy stawiane przez literaturoznawstwo. Za hermeneutyczny trudno również uznać pomysł Piotra Sterczewskiego, który w swoim tekście o czytaniu gry proponuje zastosować retorykę proceduralną lana Bogosta. Por. P. Sterczewski Czytanie gry, "Teksty Drugie” 2012 nr 6, s. $214-218$.

R. Kochanowicz „Cybernetyczne doświadczenia”..., s. 122.

Por. P. Ricœur Konflikt hermeneutyk: epistemologia interpretacji, przeł. J. Skoczylas, w: tegoż Egzystencja i Hermeneutyka, Pax, Warszawa 1985, s. 133-134.

17 Zob. R. Kochanowicz „Cybernetyczne doświadczenia”..., s. 123-125. 
tragizm"18, czyli stawiają graczy w sytuacjach bez wyjścia, w których muszą oni dokonywać wyborów wbrew sobie, poddając się dyrektywom tekstu ${ }^{19}$. Trzymając się klasycznego, Ricœurowskiego znaczenia owych dwóch stylów hermeneutyki, niekoniecznie trzeba je modyfikować, warto wszakże zwrócić uwagę na wskazany przez Kochanowicza istotny aspekt teatralności gier wideo. Co więcej, polski badacz w swojej książce wprowadził już wcześniej kategorię marionetki/wirtualnej kukiełki ${ }^{20}$, pozwalającą uniknąć problematycznych - ze względu na metafizykę obecności ${ }^{21}$ - pojęć, takich jak np. awatar czy cyberciało. Projekt hermeneutyki gier wideo jest nastawiony właśnie na wykorzystanie dostępnych pojęć czy kategorii literaturoznawczych (teatrologicznych, kulturoznawczych etc.) czy teoretycznoliterackich, podstawowym jego założeniem jest bowiem to, że gry komputerowe można z powodzeniem analizować $\mathrm{i}$ interpretować przy użyciu teorii i pojęć z dziedziny nauk humanistycznych, bez konieczności bezpośredniego badania ich mechaniki, kodu czy aspektów technologicznych z nimi związanych. Medialność gier nie stanowi zatem przeszkody w zorientowanym na tekstualność gry projekcie hermeneutyki gier wideo. Przyjmuję za punkt wyjścia refleksję Paula Ricœura, ponieważ w licznych swoich opracowaniach dotyka on problemów, które wydają się kluczowe dla analizy i interpretacji gier. Można do nich zaliczyć: namysł nad interpretacją symboli, tekstów, metafor, nad budowaniem narracji, działaniem w tekście, dialektyką rozumienia i wyjaśniania, a także nad problematyką tożsamości, wreszcie, nad kwestią utopii i ideologii. Te węzłowe punkty w myśli Ricœura wiąże nić refleksji etycznej i postawa teoretycznej otwartości na różne stanowiska badawcze, znajdziemy tu bowiem nie tylko odniesienia do klasycznej teorii literatury, myśli strukturalnej i poststrukturalnej, ale także do antropologii i etnografii, psychoanalizy, marksizmu etc. Zaskakujące jest to, że wśród legionu badaczy gier wideo z kręgu game studies (poza wyjątkami, jak Arjoranta, Vella czy Harviainen) próżno szukać myślicieli odwołujących się do Ricœura. Zupełnie pomijają go Sicart, Frans Mäyrä22 ${ }^{2}$, Sherry Turkle,

Tamże, s. 126

Tamże, s. 126-127.

R. Kochanowicz Fabularyzowane gry komputerowe..., s. 44-45.

Zob. T. Boellstorff Dojrzewanie w Second Life. Antropologia człowieka wirtualnego, przeł. A. Sadza, Wydawnictwo UJ, Kraków 2012, s. 154.

Zob. F. Mäyrä An Introduction to Game Studies. Games in Culture, Sage, London 2008. 
Espen Aarseth, Jesper Juul, Gonzalo Frasca, Tom Boellstorff, Mary-Laure Ryan etc. Nie wspominają o nim również badacze polscy, jak np. Mirosław Filiciak $^{23}$, Jan Stasieńko (jeden przypis - i to nie bezpośredni ${ }^{24}$ ), Dominika Urbańska-Galanciak ${ }^{25}$, Radosław Bomba ${ }^{26}$ czy Piotr Kubiński ${ }^{27}$. Wymienieni badacze nie popełniają oczywiście błędu, nie odnosząc się do myśli Ricœura, nie jest to w żadnym wypadku z mojej strony czyniony ich tekstom zarzut, chciałbym tylko podkreślić, że Ricœur i jego hermeneutyczne rozważania nie znalazły się, jak dotąd, w orbicie zainteresowań badawczych znawców gier.

\section{Hermeneutyka gry}

Mimo wielu definicji gier wideo wypracowanych przez przywołanych wcześniej badaczy wybór jakiejkolwiek z nich wydaje się - przynajmniej z perspektywy literaturoznawstwa i hermeneutyki - zbędny ${ }^{\mathbf{2}}$. Jeżeli traktujemy gry na równi z innymi tekstami kultury, to ścisłe ich definiowanie napotyka ten sam problem, który pojawił się dekady wcześniej w teorii literatury, a który dotyczył pytania o to, czym jest literatura. Odpowiedź na pytanie o to, czym jest gra, będzie zatem podobna do odpowiedzi, jakiej udzielił Jonathan Culler na pytanie o to, czym jest literatura: gry to teksty, które badacz określi jako gry (przez analogię: literatura jest tym, co określimy jako literaturę, chwasty

Zob. M. Filiciak Wirtualny plac zabaw. Gry Sieciowe i przemiany kultury współczesnej, Wydawnictwa Akademickie i Profesjonalne, Warszawa 2006.

Zob. J. Stasieńko Alien vs Predator? Gry komputerowe a badania literackie, Wydawnictwo Naukowe Wyższej Szkoły Edukacji TWP, Wrocław 2005, s. 194.

Zob. D. Urbańska-Galanciak Homo players. Strategie odbioru gier komputerowych, Wydawnictwa Akademickie i Profesjonalne, Warszawa 2009.

Zob. R. Bomba Gry komputerowe w perspektywie antropologii codzienności, Wydawnictwo Adam Marszałek, Toruń 2014.

27 Zob. P. Kubiński Gry wideo. Zarys poetyki, Universitas, Kraków 2016.

28 W tym miejscu widać wyraźną różnicę między założeniami hermeneutyki Sicarta czy Arjoranty, a stanowiskiem wypracowywanym w ramach niniejszego projektu: Sicart adaptuje w swojej analizie etyki gier wideo strukturalną definicję Jespera Juula, natomiast Arjoranta przyjmuje podejście Wittgensteinowskie, opierające się na podobieństwie rodzinnym. Por. M. Sicart The Ethics of Computer Games, s. 25, 35. A także: J. Arjoranta Game definitions: A Wittgensteinian approach, "Game Studies” 2014 Vol 14, No.1, s. 3, http://gamestudies.org/1401/articles/arjoranta (04.07.2016). Reprint tego artykułu jest również dostępny w: J. Arjoranta Real-Time Hermeneutics... Zob. Także. R. Kochanowicz Fabularyzowane gry komputerowe..., s. 18. 
to te rośliny, których ogrodnik nie chce widzieć w swoim ogrodzie) ${ }^{29}$. Hermeneutyka gier komputerowych będzie zatem stała na stanowisku, że to od interpretatora zależy, czy określi dany tekst kultury jako grę komputerową, czy też jako grę w ogóle, ponieważ tworzenie sztywnych wyznaczników i strukturalnych podziałów czy typologii zawsze już opiera się na mechanizmie egzekwowania władzy wobec omawianych tekstów i, koniec końców, staje się praktyką polityczną.

Hermeneutyka gier wideo nie skupia się zatem na definiowaniu gier, co wcale nie oznacza, że nie stawia ona pytań o znaczenie słowa "gra”. W swoich pismach Ricœur dotknął tej kwestii, odnosząc się do tez Hansa-Georga Gadamera postawionych w jego rozprawie o Prawdzie i metodzie, w której analizuje on właśnie istotę znaczenia tego słowa. Gadamer pisze:

Sposób istnienia gry nie jest więc tego rodzaju, że musi istnieć jakiś grający podmiot, aby gra mogła być rozgrywana. Najbardziej pierwotny sens grania jest raczej sensem medialnym. Dlatego mówimy, że coś gdzieś lub kiedyś »gra«, że coś się rozgrywa, że coś jest w grze.

Ta obserwacja językowa, jak mi się wydaje, wskazuje pośrednio na to, że gry w ogóle nie można rozumieć jako pewnego rodzaju działania. Dla języka właściwym podmiotem gry właściwie nie jest subiektywność kogoś, kto wśród innych działań także gra, lecz sama gra. Tylko że do tego stopnia przywykliśmy fenomen typu gry odnosić do subiektywności i jej sposobów zachowania, że nie chcemy dostrzec tych sugestii ducha języka. ${ }^{30}$

Ta teza Gadamera, wysnuta z badań nad metaforycznym funkcjonowaniem pojęcia gry w języku, skłania nas do przemyślenia fenomenu gry komputerowej, którego, wedle tej analizy ejdetycznej, nie da się sprowadzić do podmiotowości grającego. Powtórzmy tę tezę, aby podkreślić jej wydźwięk: Właściwym podmiotem gry komputerowej nie jest subiektywność gracza. Co więcej, gra nie potrzebuje gracza, aby mogła być rozgrywana ${ }^{31}$. Gadamer

J. Culler Teoria literatury. Bardzo krótkie wprowadzenie, przeł. M. Bassaj, Prószyński i S-ka, Warszawa 2002, s. 31-32. H.-G. Gadamer Prawda i metoda, zarys Hermeneutyki filozoficznej, przeł. B. Baran, Inter Esse, Kraków 1993, s. 123. 
pokazuje, że język mówiący o grze od zarania dziejów wcale nie kieruje się ku podmiotowości grającego w nią podmiotu, ale że jest on raczej nastawiony na jej sens medialny (w znaczeniu zwrotnej strony czasownika).Teza, że podmiotem gry komputerowej nie jest gracz, wydaje się kontrowersyjna, ujawnia wszakże bardzo ważny aspekt gry w ogóle, a tym bardziej gry komputerowej: że właściwym jej podmiotem jest ona sama wraz ze swoimi mechanizmami, które rozgrywają się niezależnie od subiektywności grającego. Przykład: w grze Deus EX: Bunt Ludzkośc ${ }^{32}$ gra toczy się bez względu na to, czy ja jako subiektywność, podmiot czy gracz gotuję obiad, umieram, dłubię w nosie czy myślę o własnej egzystencji. Grze Deus EX: Bunt Ludzkości nie jestem do niczego potrzebny, rozgrywa się ona, kiedy mnie nie ma, o czym dobitnie świadczy fakt, że może ona działać niezależnie od tego, czy podłączone są do niej narzędzia mojej ingerencji, pozwalające jej zarazem wysyłać mi informacje zwrotne. Mogę odłączyć klawiaturę, mysz, monitor, głośniki etc., a ona nadal, nieubłaganie będzie się toczyć, całkowicie poza moją subiektywnością. Tym, czego gra komputerowa potrzebuje, są, technicznie rzecz ujmując, minimalne wymagania sprzętowe pozwalające ją uruchomić, poza nimi podmiot-gracz jest absolutnie nieistotny. Gadamer postuluje, aby gry nie rozumieć jako działania, ponieważ sam medialny sens realizuje się w niej poza mną, jej istotą jest bowiem nieustanne powtarzanie ruchu tam i z powrotem:

Zawsze chodzi tu [w grze - M.K.] o pewien ruch w tę i wewtę, nie związany z żadnym celem, do którego by prowadził. Odpowiada temu także podstawowe znaczenie "gry” jako tańca, które przetrwało jeszcze w rozmaitych formach słownych (np. w słowie "grajek"). Ruch będący grą nie ma żadnego celu, na którym by się kończył, lecz odnawia się przez nieustanne powtarzanie. Ruch w tę i wewtę jest dla określenia gry tak centralny, że pozostaje już obojętne, kto lub co ten ruch prowadzi. Ruch gry jako taki odbywa się jakby bez nosiciela. To gra jest rozgrywana lub się rozgrywa - nie decyduje o tym żaden grający podmiot. Gra jest procesem ruchu jako takim. ${ }^{33}$

grania nie jest aberracją, ale fundamentalną częścią istoty gry: «wszelkie granie jest byciem granym»". .. Arjoranta Real-Time Hermeneutics..., s. 39. 
Refleksja Gadamera jest dla nas ważna, ponieważ, po pierwsze, pozwala przemyśleć istotę gry komputerowej zawartą w niej samej, niezależnie od gracza. I, po drugie, pozwala się od owej istoty gry zdystansować oraz wskazać ten jej element, który bezwzględnie domaga się interpretacji. Gra komputerowa może całkowicie w swoim medialnym - czyli zwrotnym - sensie odbywać się poza graczem, jej podstawowy i nieredukowalny mechanizm działa bowiem niezależnie od niego - jako ów „ruch w tę i wewtę”, który podtrzymuje jej działanie. Hermeneutyka gry komputerowej bierze pod uwagę ten aspekt jej samowystarczalności, ponieważ to właśnie w opozycji do niego rysuje się właściwy jej przedmiot - opowieść. O ile gra, jako czysty proces ruchu, nie wymaga dla swojego sensu mojej podmiotowości, o tyle opowieść w grze nie może istnieć poza mną, bez spotkania ze mną, bez moich subiektywnych sensów (lub konkretyzacji - jeśli trzymać się języka fenomenologii, etc.).

Powtarzalność i mechaniczność gry według Gadamera wynikają z jej medialnego sensu i służą relaksowi, dlatego że gracz zostaje zwolniony z właściwego wysiłku swojego bycia. Gadamer pisze:

Grę cechuje to, że ruch odbywa się nie tylko bez celu i zamysłu, ale też bez wysiłku. Odbywa się jakby sam z siebie. Łatwość gry, która oczywiście nie musi być rzeczywistym brakiem wysiłku, lecz oznacza tylko fenomenologicznie nieobecność trudu, jest doświadczana subiektywnie jako relaks. Reguły gry pozwalają graczowi niejako zatracić się w sobie i uwalniają go od zadania inicjatywy stanowiącej właściwy wysiłek jestestwa. Ujawnia się to w spontanicznej skłonności gracza do powtarzania i w stałym odnawianiu się gry, które nadaje jej formę (np. refren). ${ }^{34}$

Zwróćmy uwagę, że owo zwolnienie gracza z wysiłku polega według Gadamera nie na fizycznym uwolnieniu go od trudności, ale na uwolnieniu go od własnego jestestwa, od własnego bycia. Można odnieść to spostrzeżenie do gry komputerowej. W grze Deus Ex: Bunt Ludzkości owa powtarzalność i odnawialność gry będzie się spełniać w ciągłym strzelaniu do przeciwników, ogłuszaniu ich lub skradaniu się, albo na kombinacji tych powtarzalnych elementów, nie wspominając już o powtarzalności zapewnionej od pierwszego momentu przez ustanowione w grze reguły, do których gracz musi się - siłą rzeczy - dostosować. Teoria Gadamera w jasny sposób pozwala na wyraźne rozgraniczenie właściwej grze powtarzalności, mechaniki - jej sensu 
medialnego, który nie angażuje bycia do wysiłku egzystencjalnego, od tego, co będzie przedmiotem moich dalszych rozważań, czyli sensu wynikającego właśnie z zaangażowania bycia w wysiłek rozumienia. Do tych założeń odnosi się Ricœur w swojej refleksji na temat relacji między grą i przedstawieniem świata, które zawsze już jest przedstawieniem określanym przezeń jako „igrające”35. W tym znaczeniu gra jest już zawsze elementem każdego przedstawienia, ponieważ stanowi część samego procesu rozumienia, który jest efektem dialektyki fikcji i reprezentacji. Ricœur pisze:

W grze nic nie jest na serio, coś jednak zostaje ukazane, przedstawione, dane jako naśladownictwo. Rodzi się więc osobliwa relacja między grą a przedstawieniem świata. Relacja ta, co więcej, jest w pełni wzajemna: z jednej strony, przedstawienie świata w utworze jest heurystyczną fikcją i w tym sensie czymś zabawowym, ale, z drugiej strony, we wszelkiej grze ujawnia się coś prawdziwego, właśnie dlatego, że jest to gra. Bawić się, powiada Gadamer, to grać w coś. Przyjmując grę oddajemy się jej, porzucamy siebie wkraczając w obszar znaczenia, który nad nami jako czytelnikami zdobywa władzę. ${ }^{36}$

Badacz pokazuje, że oddanie się grze, czyli uwolnienie się od własnego bycia, jest poddaniem się określonemu obszarowi znaczeń. Hermeneutyka gier wideo musi opierać się na tej tezie, ponieważ pozwala ona na wskazanie specyficznej zbieżności między literaturą jako grą z jednej strony i grą jako literaturą z drugiej. Na takie traktowanie gry jako tekstu zwraca uwagę Kochanowicz, który również odnosi się do przytoczonych zdań, aby pokazać, że: „Fikcyjny w planie fabularnym charakter ujętej w grze historii już sam z siebie domaga się interpretacji" ${ }^{\text {". }}$. Mowa w tym miejscu o specyficznej rozbieżności między medialnością gry a tym, co jest przedmiotem jej przedstawienia. O tej rozbieżności jako specyficznej dla gier pisze także Juul, określając je jako półrzeczywiste (Half-real), skoro są zarazem realne, na poziomie swych zasad i możliwości odniesienia zwycięstwa lub porażki, i fikcyjne na poziomie świata przedstawionego ${ }^{38}$. Co więcej, Juul wskazuje również na istotną 
z perspektywy hermeneutyki gier wideo konsekwencję rozróżnienia reguł gry i fikcji, jaką jest konieczność dostrzeżenia ich dialektykii3. Projekt hermeneutyki gier wideo stanowi jednakże propozycję alternatywną dla określenia gier jako półrzeczywistych. W rozważaniach Juula dominuje wyraźne oddzielenie tego, co Huizinga nazywa „magicznym kręgiem” ${ }^{\text {, }}$, od świata rzeczywistego. Ricœur zmierza w innym kierunku, dlatego też w jego dyskursie nie ma mowy o magicznym kręgu, omawia on natomiast Gadamerowskie pojęcie przemiany (Verwandlung), która polega na paradoksalnej metamorfozie rzeczywistości, dokonującej się pod auspicjami wyobraźni. Ricœur pisze:

Rzeczywistość codzienna zostaje zniesiona, a jednak każdy staje się sobą. Tak więc dziecko, przebierając się za kogoś innego, wyraża swoją najgłębszą prawdę. Grający „naprawdę” ulega metamorfozie, w rozigranym przedstawieniu pojawia się „to, co jest”. Ale „to, co jest”, to już nie rzeczywistość codzienna. Rzeczywistość staje się nią naprawdę, obejmując przyszły widnokrąg nie rozstrzygniętych jeszcze możliwości, lęków i nadziei. Sztuka obala jedynie rzeczywistość nie przekształconą. Stąd prawdziwa mimêsis: metamorfoza zgodna z prawdą. ${ }^{41}$

Wydawałoby się, że Juul i Ricœur piszą o tym samym zjawisku, a jednak za sprawą zmiany akcentów ten drugi mówi o tym, co dzieje się w grze, w kategoriach prawdy. Znika podział na rzeczywiste i fikcjonalne i cała dialektyka wpisana przez Juula w łączący i zarazem przeciwstawiający te pojęcia dywiz. Metamorfoza rzeczywistości za sprawą fikcji stanowi podstawowy problem, jaki refleksja Ricœurowska stawia przed hermeneutyką gier wideo. Jak pisze Anna Łebkowska:

Konfrontacja z nieprzejrzystością [...] łączy się z osadzeniem w świecie, w którym jesteśmy, łączy się zatem z pokorą wobec świata i zarazem z możliwością przekraczania jego horyzontu. Tu zarazem - jak wiadomo - odsłania się funkcja fikcji w procesie konfiguracji i rekonfiguracji świata rzeczywistego. ${ }^{42}$

Tamże, s. 166.

Tamże, s. 164-165.

P. Ricœur Język, tekst, interpretacja, s. 279.

A. Łebkowska Między teoriami a fikcją literackq, Universitas, Kraków 2001, s. 88-89. 
Łebkowska pokazuje zatem, że Ricœur, kontynuując projekt hermeneutyki Heideggerowskiej, przyznaje fikcji, a więc całej sztuce, olbrzymią rolę w przekształcaniu rzeczywistości. Nie ma dla nas, z tej perspektywy, znaczenia to, czy gry są „półrzeczywiste”, ponieważ w takiej samej mierze jak inne dzieła sztuki zmieniają one świat rzeczywisty. Budowanie hermeneutyki gier wideo na tym podstawowym założeniu polegałoby zatem na uznaniu, że fikcja w grach nie stoi w opozycji do rzeczywistości i nie jest również jej rozszerzeniem, ale że tą rzeczywistość opisuje, konfiguruje i rekonfiguruje. Dostrzeżenie w grach tej samej istoty, która stanowi o sile literatury, filmu i innych tekstów kultury, pozwala na postawienie podstawowych pytań, które mają w swoim wymiarze hermeneutycznym charakter pytań egzystencjalnych, jak np. co gro mówisz mi o rzeczywistości?, jak ją przekształcasz?, jak konfigurujesz moją rzeczywistość za pomocą fikcji? itd. Są to pytania stare jak świat i w dużej mierze obecne w dyskursie towarzyszącym grom wideo, przecież rolą hermeneutyki gier jest stawianie ich wciąż od nowa, udzielanie i rozbudowywanie odpowiedzi na nie. Z tego powodu hermeneutyka gier wideo wspierałaby się na ponownym przemyśleniu wielu problemów game studies właśnie z wykorzystaniem filozofii Ricœura, ponieważ jego hermeneutyka stawia pytania bliższe klasycznym analizom i interpretacjom literaturoznawczym.

\section{Hermeneutyka a opowieść w grze}

Projekt hermeneutyki gier za punkt wyjścia przyjmuje Ricœurowską teorię narracji, co zasadniczo odróżnia go od np. zorientowanych kognitywnie, transmedialnie lub postklasycznie, narratologicznych modeli badania gier wideo autorstwa Mary-Laure Ryan ${ }^{43}$, Jana-Noëla Thona i innych ${ }^{44}$.

43 Nie można w tym miejscu zapominać, że Ryan - mimo reprezentowania innego podejścia narratologicznego niż Ricœur - zapisuje tezy bardzo istotne dla badania opowieści w grach: „O ile działania graczy sprawiają, że ten świat ewoluuje, gry komputerowe ujawniają wszystkie podstawowe składniki narracji: postaci, zdarzenia, tło i trajektorie prowadzące z punktu początkowego do końca. Można podsumować, że wyjątkową zdobyczą gier komputerowych, w porównaniu z grami planszowymi i sportem, jest to, że włączyły one grę do narracji i fikcyjnej ramy". M.-L. Ryan Avatars of Story, University of Minnesota Press, London 2006, s. 182.

Por. J.-N. Thon Transmedial Narratology and Contemporary Media Culture, University of Nebraska Press, Lincoln 2016. Oraz F. Zipfel Fiction across Media: Toward a Transmedial Concept of Fictionality, w: Storyworlds Across Media. Toward a Media-Conscious Narratology, ed. by M.-L. Ryan, J.-N. Thon, University of Nebraska Press, Lincoln 2014, S. 103-125. Na temat narratologii transmedialnej w polskich badaniach gier zob. K. Kaczmarczyk Narratologia transmedialna. Założenia, cele wyzwania, „Tekstualia” 2015 nr 4, s. 3-16. Warto zwrócić uwagę, że narrato- 
Wyjście od problematyki narracji pozwala połączyć trzy istotne dla filozofii Ricœura obszary badawcze w spójny projekt namysłu nad grami, na który składają się: studium Metafory żywe ${ }^{45}$, analizy z Czasu i opowieści ${ }^{46}$ oraz rozprawa nad problematyką tożsamości $O$ sobie samym jako innym ${ }^{47}$. Zasadniczą syntezę dwóch pierwszych opracowań przedstawia artykuł Ricœura O interpretacji ${ }^{48}$.

Na pierwszy plan wysuwa się kwestia narracyjności gier, a dokładniej rozumienia gier jako opowieści. Hermeneutyka dystansuje się wobec tzw. sporu ludologów z narratologami ${ }^{49}$, przyjmując pośrednie stanowisko naszkicowane przez Fraskę, co wcale nie powoduje, że sam problem opowieści w grach przestaje być istotny. Projekt hermeneutyki gier przyjmuje podstawową tezę Ricœura o tym, że najważniejszym i spajającym wszystkie formy ludzkiego doświadczenia i opowiadania elementem jest czasowość. Pisze on:

Albowiem moja podstawowa hipoteza brzmi następująco: wspólną cechą doświadczenia ludzkiego uwydatnianego, wyrażanego, wyjaśnianego przez akt opowiadania we wszystkich jego formach jest jego czasowość.

logie postklasyczne dystansują się od myślenia o narracji w kategoriach Arystotelesowskich, czyli również od stanowiska reprezentowanego przez Ricœura, stąd próżno w opracowaniach na temat narracji transmedialnych szukać odniesienia do jego pism, a sam Thon na moje pytanie o Ricœura podczas konferencji Mind - Media-Narrative (Warszawa 20-22 czerwca 2016) odpowiedział, że nie jest on narratologiem sensu stricto. P. Ricœur La métaphore vive, Éditions du Seuil, Paris 1975. P. Ricœur Czas i opowieść, przeł. M. Frankiewicz, Wydawnictwo UJ, Kraków 2008. P. Ricœur O sobie samym jako innym, przeł. B. Chełstowski, PWN, Warszawa 2003. P. Ricœur O interpretacji, przeł. J. Margański, w: Teorie literatury XX wieku. Antologia, red. A. Burzyńska, M.P. Markowski, Znak, Kraków 2006, s. 193-212. mi pisał we wstępie do swojego artykułu Piotr Sterczewski Czytanie gry, s. 210-213. Zob. także omówienie sporu ludologów z narratologami w innym artykule Sterczewskiego: tegoż Dlaczego nie przespałem się z Vesna Hood. Kilka uwag o warsztacie pracy badacza gier komputerowych, w: Twórca - Dzieło - Badacz. Między dyscyplinami humanistyki, red. E. Januszek, M. Jarząbek, M. Kobielska, Wydawnictwo UJ, Kraków 2013, s. 72-73. Sterczewski cytuje fragment tekstu Aarsetha, w którym ten klasyk badań nad grami wyraźnie wskazuje, że ludologia zajmuje się grami w ramach "badań empirycznych", co z góry przeczy przyjętym w projekcie gier wideo założeniom lektury idiograficznej. Zob. również G. Frasca Ludolodzy też kochajq opowiadania - notatki na temat sporu, który nigdy nie miał miejsca, przeł. M. Filiciak, w: Światy z pikseli. Antologia studiów nad grami komputerowymi, red. M. Filiciak, SWPS Academica, Warszawa 2010, s. 78-89. 
Wszystko, co się opowiada, wydarza się w czasie, wymaga czasu, rozwija się czasowo; a to, co rozwija się w czasie, daje się opowiedzieć.50

Ponieważ gry wideo odbywają się w czasie, dają się opowiedzieć, a co za tym idzie, są one od początku do końca nierozerwalnie związane z opowieścią jako określonym konfigurowaniem czy rekonfigurowaniem ludzkich doświadczeń. Już sama możliwość opowiedzenia gry czyni z niej pośrednio przedmiot namysłu hermeneutyki, ponieważ uświadamia nam, że gry uruchamiają ten sam, podstawowy mechanizm, który zbliża je do literatury: chęć interpretacji, czyli rozumienia, pracy z sensem i nad sensem.

Tu dochodzimy do kolejnego wątku refleksji Ricœura, jaki niniejsza propozycja hermeneutyki gier przyjmuje za swą podstawę. Gry ujęte w ramach systemów symbolicznych, właśnie dlatego że opowiadają o czymś w ramach swojej czasowości, konfigurują rzeczywistość:

Wszystkie systemy symboliczne w ten czy inny sposób przyczyniają się do konfigurowania rzeczywistości. Zwłaszcza wymyślane przez nas intrygi pomagające nam skonfigurować nasze doświadczenie czasowości - bezładne, bezkształtne i bezgranicznie nieme..$^{51}$

Ricœur pokazuje, że sztuka intrygowania jest sztuką nadawania głosu ludzkim doświadczeniom czasowości, z czego wynikałoby, że także gry wideo konfigurują to, co „bezładne, bezkształtne i bezgranicznie nieme”52. Ale intrygowanie odbywa się już zawsze dzięki graczowi-czytelnikowi, ponieważ to na nim spoczywa wysiłek wyjaśniania i rozumienia, także wyjaśniania i rozumienia własnych wyborów w grze, a zatem i konfigurowania oferowanych przez nią elementów intrygi. Na plan pierwszy wysuwa się zatem kwestia fikcyjności wirtualnych światów gier wideo, a na plan dalszy odsuwa struktura narracyjna. Badacz podpowiada, że „Fikcja to tyle co fingere, a fingere to tyle co robić. Świat fikcji w owym stadium zawieszenia jest światem wyłącznie tekstowym, projekcją tekstu jako świata"53. Przyjmijmy zatem, że świat wirtualny to świat fikcji, świat zrobiony, napisany, tekstowy. W konsekwencji świat

\footnotetext{
50 Paul Ricœur O interpretacji, s. 194.

51 Tamże, s. 198.

52 Tamże.

53 Tamże.
} 
gry pozostanie zawsze w relacji do świata rzeczywistego i w kolizji z nim. Jak pisze Ricœur:

Świat tekstu, będąc wszak światem, wchodzi nieuchronnie w kolizję ze światem rzeczywistym, by go „przerobić” [ refaire] - już to potwierdzając, już to go negując. Jednakże nawet najbardziej ironiczny stosunek do rzeczywistości byłby niezrozumiały, gdyby sztuka nie zakłócała i nie aranżowała na nowo naszego stosunku do rzeczywistości. ${ }^{54}$

Z całą powagą należałoby, w ramach proponowanej hermeneutyki, podjąć analizę i interpretację owej dialektyki świata gier i świata rzeczywistego, traktując grę na równi z innymi formami sztuki, jako tekstami zmieniającymi nasz stosunek do rzeczywistości. Pytać, w jaki sposób gry przepisują, przetwarzają problemy, które obserwujemy w rzeczywistości, w jakiej mierze one same stanowią ważne interpretacje, pomagające rozumieć człowiekowi jego świat. Fikcja gier wideo okazywałaby się jednym ze sposobów, w jaki człowiek współczesny zamieszkuje swój świat, a zatem także w jaki sposób rozumie i postrzega samego siebie w tym świecie. Podsumowaniem powyższych założeń jest postawiona przez Ricœura teza na temat braku rozróżnienia między „doświadczeniem a doświadczeniem empirycznym”. Włączając teorię metafory do swoich rozważań na temat opowieści. pisze on:

Tymczasem poprzestańmy na stwierdzeniu, że funkcja przekształcania rzeczywistości, którą przyznajemy fikcji poetyckiej, zakłada, że przestajemy rozróżniać rzeczywistość i rzeczywistość empiryczną albo - co na jedno wychodzi - że przestajemy rozróżniać doświadczenie i doświadczenie empiryczne. Język poetycki czerpie swój autorytet ze zdolności do nadawania językowi cech, jak to nazywał Husserl, Lebensweltu czy Heideggerowskiego In-der-Welt-Sein. ${ }^{55}$

Ricœur twierdzi zatem, że język fikcji poetyckiej staje się językiem nacechowanym tak jak świat ludzkiego życia. Podkreślenia wymaga słowo „nacechowany”, ponieważ gdyby pominąć ten istotny i różnicujący aspekt wypowiedzi francuskiego filozofa, można by było bezkrytycznie powtórzyć

\footnotetext{
54 Tamże, s. 198-199.

55 Tamże, s. 204.
} 
tezę Daniela Velli, który określa świat gry mianem Lebensweltu ${ }^{56}$ właśnie. Odniesienie do tez Ricœura pozwala ominąć ontologiczną pułapkę wiary w to, że świat gry jest światem życia czy że jest możliwe bycie wrzuconym w tenże świat bez możliwości wyjścia, jak sugeruje Heideggerowskie pojęcie bycia w świecie (In-der-Welt-Sein) ${ }^{57}$. Do pojęcia Heideggera faktyczności bycia w świecie Ricœur dopisuje pojęcie potencjalności-możliwości, dzięki czemu jest w stanie wskazać właściwe miejsce napięcia i dialektyki fikcji i rzeczywistości ${ }^{58}$. Dlatego też stawia tezę, która pozwala przyjąć, że fikcja powoduje rzeczywiste ludzkie działanie. Pisze:

Na płaszczyźnie narracyjnej wciąż ta sama wymiana między sobą ulegającym wpływowi a wpływającym innym sprawia, że czytelnik opowieści bierze na siebie role odgrywane przez postaci, tworzone najczęściej w trzeciej osobie, w tej mierze, w jakiej są one wraz z opowiadaną akcją tworzywem zawiązania intrygi [...]. Okazuje się więc, że wpływanie na tego-który-jest-sobą przez innego niż sam znajduje w fikcji wyróżnione środowisko myślowych doświadczeń, którego nie mogą zaćmić „rzeczywiste" stosunki rozmowy i interakcji. Wręcz przeciwnie, odbiór dzieł posługujących się fikcją przyczynia się do wyobrażeniowego i symbolicznego ustanowienia faktycznych procesów wymiany słowa i działania. Tak więc byt-pod-wpływem wedle wzoru fikcyjnego zostaje włączony do bytu-pod-wpływem [właściwego] temu-który-jest-sobą wedle wzoru "rzeczywistego".59

Ricœur tłumaczy zatem, na jakiej zasadzie fikcja nie tylko pomaga rozumieć świat i samego siebie, ale w jaki sposób fikcja wpływa na faktyczne działania w nie mniejszym stopniu niż rzeczywiste stosunki czy interakcje. W tym miejscu warto przywołać myśl filozofa przytoczoną na początku niniejszego tekstu, że „dziecko, przebierając się za kogoś innego, wyraża swoją najgłębszą prawdę"60. Zaangażowanie w fikcję i za sprawą fikcji jest właściwie testowaniem potencjalności-możliwości, testowaniem siebie, norm moralnych,

D. Vella The Ludic Subject and the Ludic Self..., s. 93.

58 Tamże, s. 524.

59 Tamże, s. 547-548.

60 P. Ricœur/ęzyk, tekst, interpretacja, s. 279. 
etycznych, wartości, przekonań etc. Granie w gry wyraża prawdę dlatego, że między fikcją i rzeczywistością występuje ciągłe napięcie, które polega na doświadczaniu tego, co fikcyjne, jak tego, co rzeczywiste ${ }^{61}$.

Wymienione problemy pozwalają na podsumowanie założenia projektu hermeneutyki gier wideo jako refleksji nad tym, w jaki sposób fikcja w grach wideo pozwala lepiej zrozumieć problemy współczesnego bycia. Co więcej, dzięki przyjęciu rozważań Ricœura z rozprawy $O$ sobie samym jako innym, hermeneutyka dostrzega w analizie i interpretacji gier wideo niekończący się proces pytania o relację z innym, którego gracz bierze na siebie w ramach gry, dzięki któremu wyraża swoją najgłębszą prawdę, konstruuje część siebie, konstruuje własną historię i tożsamość narracyjną. Rozważania nad byciem sobą jako innym w grze i poprzez grę stanowią zatem ten problem hermeneutyki, który nigdy nie zostaje do końca rozwiązany, a jednocześnie bez którego pytania stawiane grom tracą istotny wymiar egzystencjalny. Niniejszy projekt dystansuje się zatem od proponowanych przez Aarsetha badań empirycznych nad grami, jego podstawą jest bowiem przyjęcie za Ricœurem tezy, że fikcyjność gier pozwala zawiesić rozróżnienie na doświadczenia empiryczne $\mathrm{i}$ inne, ponieważ w ramach fikcji ten-który-jest-sobą spotyka się z jednym z wymiarów własnej inności.

61 To zorientowanie na fikcję odróżnia proponowany przeze mnie projekt od skądinąd ciekawej refleksji de Mula, który również podejmuje refleksję nad ludzką egzystencją, ale z perspektywy pojęcia tożsamości ludycznej. 


\section{Abstract}

\section{Michał Kłosiński}

UNIVERSITY OF SILESIA (KATOWICE)

Towards a Hermeneutics of Computer Games

This article presents the project of a hermeneutics of computer games as an alternative to current game studies. Kłosiński builds on Paul Ricœur's work - in particular his reflections on Hans-Georg Gadamer's game theory and on fiction in literature - as Ricœur helps raise questions about video games as cultural texts. Examining the issue of the literariness of video games as well as methods for their analysis and interpretation, Kłosiński argues that fictional computer games use fiction to configure and reconfigure reality as well as the human experience of being in the world.

\section{Keywords}

hermeneutics, computer games, Ricœur, Gadamer, fiction 